\title{
CHIŃSKA MEDYCYNA SĄDOWA - OD STAROŻYTNOŚCI DO WIEKÓW ŚREDNICH. RYS HISTORYCZNO-PRAWNY
}

\begin{abstract}
Wstęp
Niniejszy artykuł stanowi syntezę dziejów i przebiegu opiniowania sądowo-lekarskiego w Chinach w okresie od starożytności do wieków średnich. Zastosowano tu głównie dwie metody badawcze - analizę historyczną oraz analizę normatywną. Artykuł ma na celu przybliżenie wiedzy dotyczącej chińskiej medycyny sądowej w kontekście historycznoprawnym, ukazanie czynności urzędników i medyków, przedstawienie najważniejszych regulacji prawnych, a także podkreślenie wysokiego poziomu chińskiej wiedzy sądowo-lekarskiej od zarania dziejów. Warto dodać, że medycyna sądowa w Chinach (w porównaniu do Europy) ma bardzo długą historię, od dawna też korzystano z pomocy biegłych. Pierwszym w historii lekarzem medycyny sądowej i kryminalistykiem był Song Ci, żyjący w trzynastowiecznych cesarskich Chinach. W swoim dziele pt. Hsi Yuan Chi Lu (Oczyszczenie ze zła) opisał użycie niezwykłych technik antropologii sądowej w średniowieczu.
\end{abstract}

\section{Tajemnicze grobowce w Hubei}

Opiniowanie sądowo-lekarskie ${ }^{1}$ w Chinach jest znane od najdawniejszych dziejów. Chińczycy studiowali medycynę już w zamierzchłych czasach, a także osiagali w tej dziedzinie sukcesy ${ }^{2}$. Już 2000 lat p.n.e. w Anyangu pojawiły się pierwsze zapisy na kościach i skorupach żółwi wraz z rycinami, z których możemy odczytać pierwsze metody leczenia królewskiej rodziny Shang - były to m.in. zaburzenia wzroku, bóle zębów, wzdęcia brzucha ${ }^{3}$. Starożytni chińscy lekarze wiedzieli już o szczepieniach przeciwko

ORCID: 0000-0002-2986-3817, DOI: 10.4467/23538724GS.20.048.13488

1 Zob. M. Dębicka, Poczatki opiniowania sqdowo-lekarskiego na ziemiach polskich (do XVIII wieku), „Studia z Dziejów Państwa i Prawa Polskiego” 2019, t. 22, s. 51-63.

2 C.W. Wall, An Examination of the Ancient Orthography of the Jews, and of the Original State of the Text of the Hebrew Bible: The propagation of alphabets and other phonetic systems throughout Eastern Asia; and on the vast inferiority of ideographic writing, as displayed in its effects upon buman learning. 1840-1841, London 1841, s. 279.

3 J. Kaisermann, M. Pawlowski, Y. Mendel, Historia medycyny, tłum. C.S.B. Equipment, Cambridge 1990, s. 246. 
ospie, która prawdopodobnie przybyła z Indii ${ }^{4}$. Potrafili znieczulać swoich pacjentów oraz zapobiegać krwawieniu ${ }^{5}$. Chętnie zalecali lecznicze głodówki, a także picie gorącej wody w celu oczyszczenia organizmu z toksyn ${ }^{6}$. Lekarze nadworni musieli zdać trzy egzaminy, przy czym ostatni odbywał się w obecności cesarza ${ }^{7}$. Odpowiedzialność medyka była zatem wysoka, co nie przekładało się jednak na jego pozycję na dworze. Starożytna chińska medycyna opiera się głównie na ziołolecznictwie, akupunkturze, masażu. Ówcześni lekarze przywiązywali ogromną uwagę do medycyny magicznej, szukając korelacji między kosmosem a ludzkim organizmem ${ }^{8}$. Istotną rolę w medycynie odegrała koncepcja yang-yin oraz koncepcja pięciu elementów budowy świata i ich odpowiedników w ludzkim organizmie 9 . Praktyka wykonywania sekcji zwłok, aż do dynastii Zhou (1066-711 r. p.n.e.) została zaprezentowana w traktacie medycznym Huangdi Neijing (黄帝內經), który łączono z mityczną postacią Źółtego Cesarza $^{10}$. Głowę, klatkę piersiową oraz brzuch porównywano do nieba, człowieka i ziemi ${ }^{11}$. Wskaźnik ziemi wysyłał ostrzeżenia dotyczące chorego narządu do reszty

4 F.H. Garrison, An Introduction to the History of Medicine: With Medical Chronology, Suggestions for Study and Bibliographic Data, Philadelphia - London 1917, s. 67-68.

${ }^{5}$ J.H. Baas, Outlines of the history of medicine and the medical profession, New York 1889, s. 53.

${ }^{6}$ J.B. du Halde, The General History of China: Containing A Geographical, Historical, Chronological, Political and Physical Description of the Empire of China, Chinese-Tartary, Corea and Thibet, Including an Extract and Particular Accaount of Their Customs, Manners, Ceremonies, Religion, Arts and Sciences, vol. 3, London 1739, s. 365.

7 T. Brzeziński, Historia medycyny, Warszawa 2016, s. 36.

8 Zob. W.H. Welch, Papers and addresses, vol. 3, Baltimore 1820, s. 174-185.

9 Zakładano, że yang to czynnik męski (siła, witalność, aktywność, zdrowie), zaś yin to czynnik kobiecy (słabość, choroba, śmierć). Yang stanowiły wszystkie narządy barwy jasnej, zaś yin ciemne oraz ukrwione. Jeżeli przeważa yin, to występuje niedoczynność danego narządu, a przewaga yang to wzmożona czynność narządu. Inna teoria zakładała, że świat składa się z pięciu elementów - metalu, wody, ognia, ziemi, drewna. Elementy te miały swoje odpowiedniki w organizmie ludzkim i były to kolejno - płuca, śledziona, wątroba, serce, nerki. Istniały również narządy pomocnicze, którymi było jelito grube, cienkie, woreczek żółciowy, żołądek, pęcherz moczowy. Zob. F. Wallner, The Way of Thinking in Chinese Medicine: Theory, Methodology and Structure of Chinese Medicine, Frankfurt am Main 2010, s. 71; H. Murray, J. Crawfurd, P. Gordon, An Historical and Descriptive Account of China: Its Ancient and Modern History, Language, Literature, Religion, Government, Industry, Manners, and Social State, Edinburgh 1843, s. 301-303.

10 P.U. Unschuld, Huang Di Nei Jing Ling Shu, Oakland 2016, s. 14. Huang Di Nei Jing (znany jako Wewnetrzny kanon Żóttego Cesarza lub Wewnetrzna klasyka Żóttego Ksiecia) to najwcześniejsze i najważniejsze dzieło tradycyjnej medycyny chińskiej. Został opracowany ponad 2200 lat temu w Okresie Walczących Królestw (475-221 r. p.n.e.) i jest uważany za podstawowy i najbardziej reprezentatywny tekst medyczny. Wersja nominowana do wpisu do Księgi Pamięci Świata została wydrukowana i opublikowana przez Hu's Gulin Sanctum w 1339 r. techniką drzeworytu. Podzielona została na dwie części - Ksiegę Prostych Pytań (Suwen) oraz Oś witalna (Lingshu). W rzeczywistości została opracowana przez kilku autorów, zaś Żółty Cesarz jest tylko legenda.

11 P.U. Unschuld, Huang Di nei jing su wen. Nature, Knowledge, Imagery in an Ancient Chinese Medical Text, Berkeley - Los Angeles - London 2003, s. 241-246. 
ciała. Autopsje wykonywano na zmarłych w celu zbadania twardości i wielkości narządów lub określenia stanu krwi ${ }^{12}$. Najczęściej wykorzystywano do tych celów ciała skazańców. Dokonywano również oględzin zewnętrznych, które polegały na obserwacji oraz wysłuchaniu pacjenta ${ }^{13}$. Chińscy medycy zwracali szczególną uwagę na stan emocjonalny pacjenta i jego psychikę. Kierowali się m.in. tzw. zasadą blokad. Przykładowo - blokada serca miała związek z żalem, zaś blokada w wątrobie świadczyła o wyczerpaniu i zmęczeniu ${ }^{14}$. W Huangdi Neijing pojawiły się także zagadnienia związane z toksykologia, wiktymologią czy etyką lekarską. Poruszono w nim problematykę m.in. aborcji, poronienia czy samobójstwa. Traktat ten jest uważany za fundamentalne źródło chińskiej medycyny, które obejmowało teoretyczne podstawy medycyny wraz z metodami diagnostycznymi.

Autopsje medyczno-sądowe oraz badanie ran pojawiły się w księdze z zapisami obrzędów - Li Ji, a także rocznikach „Lushi Chunqui” („Wiosenne i jesienne Roczniki Mistrza Lü’” ${ }^{15}$ w okresie Zhanguo ${ }^{16}\left(\mathrm{~V}\right.$ w. - 221 r. p.n.e.) przed dynastią Qin ${ }^{17}$. Dokonywał ich wówczas urzędnik, który miał nie tylko wiedzę prawną, ale i medyczna. Badania archeologiczne przeprowadzone prawie pół wieku temu w środkowych Chinach wykazały, że opiniowanie sądowo-lekarskie funkcjonowało już w III w. p.n.e. ${ }^{18} \mathrm{~W}$ grudniu 1975 r. grupa badaczy odkryła niezwykłe zapisy na bambusowych paskach w grobowcu Quin w Shui-hu-ti, niedaleko Yiin-meng (hrabstwo Yunmeng w Hubei) ${ }^{19}$. W krypcie o numerze 11 znaleziono 1155 bambusowych wycinków. Wśród nich były opisane cztery przypadki, które z punktu widzenia niniejszego artykułu mają duże znaczenie. Dokumenty te, zatytułowane Feng Chen Shin zawierały informacje dotyczące śledztw w sprawach określonych jako „śmierć przez rabunek z przemocą, „,śmierć przez powieszenie”, „trąd”, „,poronienie”20.

12 Ibidem, s. 169.

13 Ibidem, s. 251.

14 Ibidem, s. 221-222.

15 W literaturze chińskiej spotykamy się również z określeniem Lülan 呂覽 - Badania Lu. Był to zbiór esejów wydanych pod patronatem Lü Buwei. Buwei dążył do zebrania całej wiedzy z tamtego okresu w formie encyklopedii; zob. J. Knoblock, J. Riegel, The annals of Lü Buwei. A complete translation and study, Stanford 2001.

16 Okres Walczących Królestw (戰國), czyli okres charakteryzujący się zwiększoną centralizacja, a także licznymi wojnami. Pojawiły się nowe bronie: halabardy (戟), kusze (努), rydwany (戰車), kawaleria (騎兵), a także łucznicy wspierający piechotę. W tym okresie wzrosło znaczenie medycyny wojennej.

17 C. Xinshan, H. Ruiting, The history of Chinese Forensic Medicine and science [w:] History of forensic medicine, ed. B. Madea, Berlin 2017, s. 78.

18 J.K. Fairbank, The Cambridge History of China, vol. 1: The Ch'in and Han Empires, 221 BC - AD 220, Cambridge 1986, s. 92-105.

19 Z. Wang, P. Chen, P. Xie, History and Development of Traditional Chinese Medicine, Tokyo 1999, s. 185; A. Williams, Forensic Criminology, London - New York 2014, s. 339.

20 R.D.S. Yates, The Qin Slips and Boards from Well No. 1, Liye, Hunan: A Brief Introduction to the Qin Qianling County Archives, „Early China” 2012-2013, vol. 35-36, s. 291-329. 
Mężczyzna o imieniu Hsi pojawiał się w wielu kazusach. Jak wynika $z$ analizy bambusowego tekstu, był sędzia żyjącym w latach 262-217 p.n.e. Dokumenty sądowe musiały być dla zmarłego bardzo cenne, ponieważ spoczywały razem z jego szkieletem i czaszką w krypcie. Zapiski te są niezwykle precyzyjne jak na ówczesne czasy. W pierwszym przypadku z raportu urzędnika prefektury wynika, że ofiarą przestępstwa był ,samotny mężczyzna z wiązanymi włosami, którego zwłoki leżały prosto $\mathrm{w}$ domu, $\mathrm{z}$ twarzą do góry i z głową na południe" ${ }^{21}$. Na lewej skroni widniała rana od noża, zaś z tyłu głowy długa rana o wymiarze 4 cali i szeroka na 1 cal. Z ustaleń urzędnika dokonującego oględzin ciała i pomieszczenia wynikało, że były to rany szarpane zadane siekiera, zaś ubrania były mocno poplamione krwia. Co ciekawe, badano również ślady (odciski) stóp napastnika na ziemi, a także odmierzano ich odległość od miejsca zbrodni i najbliższych miejsc (gospodarstw, posterunku).

Drugi przypadek dotyczył śmierci przez powieszenie $c h i n g s u^{22}$. Wódz wioski zawiadomił o śmierci jednego z wieśniaków. Oględziny urzędnika prefektury wykazały, że ciało wisiało na sznurze umocowanym na belce. Głowa i plecy dotykały ściany, język wystawał lekko, zaś ubranie i posadzka były pokryte ekskrementami. Lina pozostawiła na szyi siniak. Dokonując oględzin, szukano na ciele zmarłego śladów ostrza, po czym zdecydowano o przeniesieniu ciała do biura sądowego ${ }^{23}$. Po zbadaniu zwłok wysunięto wnioski, że mężczyzna faktycznie popełnił samobójstwo, zaś osobami, które mogły mieć na to wpływ, byli bliscy zamieszkujący stale ze zmarłym - żona i córki.

W trzecim przypadku urzędnik prefektury (chbu) badał płód po oczyszczeniu go w misce z woda. Kobieta była badana przez inną doświadczoną kobietę (która była jednocześnie niewolnica). Z pewnością nie były to metody dokładne, jednak eksperci starali się zrobić wszystko, co w ich mocy, by poznać prawdę. Zanurzenie płodu w wodzie nie było prawidłowym sposobem określania jego cech, tym bardziej że po wynurzeniu przypominał zniekształconą masę zakrzepłej krwi wielkości pięści²4.

Czwarty przypadek doskonale obrazuje, z jaką dokładnością starożytni Chińczycy dbali o zdrowie publiczne. Naczelnik wioski przyprowadził do sądu chorego wieśniaka, który jego zdaniem chorował na trą $\mathrm{d}^{25}$. Lekarz po zbadaniu chorego stwierdził u niego brak brwi, brak grzbietu nosa, zgniliznę w nozdrzach z brakiem czucia, zropiałe łokcie i kolana, słaby głos, brak owłosienia. Były to typowe objawy występujace u osób chorych na leprosy. Nie wspomniano jednak o karze, jaka czekala mężczyznę za brak poszanowania zdrowia publicznego.

\footnotetext{
21 D. Bodde, Forensic medicine in Pre-Imperial China, ,Journal of the American Oriental Society” 1982, vol. 102, no. 1, s. 11.

22 L. Gwei-Djen, J. Needham, A history of forensic medicine in China [w:] Medical History, vol. 32, Cambridge - London - New York 2012, s. 357-400.

23 I. Gordon, H.A. Shapiro, Forensic Medicine; a Guide to Principles, Edinburgh 1975, s. 96.

24 L. Gwei-Djen, J. Needham, A history..., s. 366.

25 Ibidem, s. 367.
} 
Duża część tekstu bambusowych pasków została poświęcona dochodzeniu sądowemu, w tym badaniu zwłok w celu ustalenia przyczyny śmierci ${ }^{26}$. Jeden z wpisów omawiał dość szczegółowo klasyczny problem późniejszej medycyny sądowej w Chinach, czyli ustalenie, czy powieszona osoba popełniła samobójstwo, czy została zamordowana ${ }^{27}$. Dokumenty z grobowców pokazywały, że lekarze oraz urzędnicy próbowali osiagać dokładność w swych badaniach, jednak było to niemożliwe z powodu braku odpowiednich informacji embriologicznych. Zachowane paski bambusowe zostały później zebrane i nazwane Yunmeng Qinjïan, stając się mieszanina prawa dynastii Qin, Fa Lu Wen Da (pytania i odpowiedzi dotyczące zagadnień prawnych) oraz Feng Zhen Shi (książki o śledztwie i medyczno-kryminalistycznych sekcjach) ${ }^{28}$. Wszystkie obdukcje czy oględziny były szczegółowo rejestrowane w formie yuanshu ${ }^{29}$, czyli oficjalnego dokumentu, którego sporządzenie było koniecznym warunkiem zbadania danej sprawy ${ }^{30}$.

\section{Feng Zheng Shi i Ling Shi}

Feng Zhen Shi (封診式), czyli Zapieczetowany wrorzec śledztwa była pierwszą książka kryminalistyczno-medyczna, która ukazywała procedury ustawy Qin. Feng Zhen Shi zawiera 25 yuanshu (raportów), dostarczając cennych informacji na temat procedury dochodzenia i ścigania ${ }^{31}$. Przedstawiono takie procedury, jak: dochodzenie i śledztwo, plombowanie mienia, aresztowanie przestępców, karanie złoczyńców oraz sekcje sądowo-lekarskie, które stanowią ponad połowę dzieła. Zgodnie z tymi zasadami Ling Shi (令史), zwani też prefektami, byli pierwszymi urzędnikami sędziowskimi, którzy dokonywali czynności sądowo-lekarskich ${ }^{32}$. Warto dodać, że w okresie starożytnym nie było takiego terminu, jak „medycyna sądowa”. Czynności wykonywane przez Ling Shi nazywano 仵 - Zuo ${ }^{33}$. W czasach dynastii Han (206 r. p.n.e. 220 r. n.e.) badania kryminalistyczne stały się popularne, zaś w okresie panowania

26 C. Furth, J.T. Zeitlin, P. Hsidung, Thinking with Cases: Specialist Knowledge in Chinese Cultural History, Honolulu 2007, s. 69.

27 Zob. P. Saukko, S. Pollak, Procedures and standards [w:] Encyclopedia of Forensic and Legal Medicine, eds. R. Byard, T. Corey, C. Henderson, vol. 2, San Diego 2005, s. 166.

28 C. Xinshan, H. Ruiting, The history of Chinese Forensic Medicine..., s. 78-79.

29 A.F.P. Hulsewe, Remnants of Ch'in Law: An Annotated Translation of the Ch'in Legal and Administrative Rules of the $3^{\text {rd }}$ Century B.C. Discovered in Yün-meng Prefecture, Hu-pei Province, in 1975, Leiden 1985, s. 183.

30 Zob. L. Wieger, China Through the Ages, Hsien Press, [b.m.] 1928, s. 222-464.

31 Y. Liu, Origins of Chinese Law: Penal and Administrative Law in Its Early Development, Hong Kong 1998, s. 210.

32 Zob. Y. Nalan, Sbì wù jì yuán bǔ: 10 Juăn, mùlù: 2 Juăn, Qiān mù táng 1806.

33 Zob. J. Zhang, The Tradition and Modern Transition of Chinese Law, Heidelberg - New York Dordrecht 2018, s. 211-229. 
dynastii Sui (581-618) i Tang (618-626) słowo 廵作 (Xún zuö) zostało upowszechnione. W czasach dynastii Song (960-1279) tego rodzaju oficjalna służba, podobna do współczesnych lekarzy medycyny sądowej, była oficjalnie nazywana w ten sposób.

Śledczy mieli za zadanie poznać fakty poprzez zadawanie pytań świadkom oraz zbieranie i badanie dowodów rzeczowych, a także skłonić podejrzanego do przyznania się ${ }^{34}$. Zabezpieczano majątek oskarżonego oraz poddawano go torturom ${ }^{35}$, co było typowe dla ówczesnego procesu śledczego ${ }^{36}$. Prawo Qin stosowało również surowe kary dla tych, którzy przekroczyli je na wiele sposobów - nawet przesłuchiwani świadkowie mogli zostać aresztowani. Tortury uznawano za niewiarygodne, jednak w praktyce dopuszczano ich stosowanie (np. bicie podczas przesłuchiwania). Warto dodać, że Feng Zheng Shi zabraniało stosowania przemocy, uznając ja za wyraz nieudolności (治獄, 能以書從迹其言册治〔笞]諒〔掠】而得人 請〔情〕鴬上, 治〔笞〕諒〔掠〕鴬下, 有恐鴬敗 $)^{37}$. Zgodnie z ustawa Qin w przypadku nieznanej przyczyny zgonu prefekci dokonywali sekcji zwłok oraz oględzin. Jeżeli uchylali się od wykonywania swoich czynności, to byli surowo karani. Cała procedura nazywana jest Fèng zhèn shi (封诊式), co można tłumaczyć jako „styl kliniki zamkniętej”. Klinika zamknięta to regulamin dotyczący zasad procesu i śledztwa, przesłuchań oraz pieczętowania dokumentów eukaliptusowych ${ }^{38}$. Jest to również najwcześniejszy standard medycyny sądowej na świecie, który zawierał dokładne opisy metody oraz zasad identyfikacji kryminalistycznej. W przypadku śmierci kluczową rolę odgrywała lokalizacja zwłok, ran wraz z ich opisem (rozmiar, kierunek), ułożenie ciała, charakterystyczne przedmioty znajdujące się blisko ciała. Feng Zhen Shi zwraca uwage na odcięte głowy, a także badania weterynaryjno-sądowe (np. badanie krowich zębów) ${ }^{39}$.

Niestety ówczesna wiedza chirurgiczna i anatomiczna była na bardzo niskim poziomie. Kult zmarłych przodków doprowadził do uznania świętości ciała ludzkiego. Między innymi konfucjaniści uważali sekcję zwłok lub drobne zabiegi chirurgiczne za profanację ${ }^{40}$. Co za tym idzie, chirurgia była słabą stroną chińskich

34 A.J. Barbieri-Low, R.D.S. Yates, Law, State, and Society in Early Imperial China (2 vols): A Study with Critical Edition and Translation of the Legal Texts from Zhangizashan Tomb no. 247, Leiden - Boston 2015, s. 184.

35 J.F. Davis, The Chinese: A general description of the empire of China and its inhabitants, vol. 2, London 1836, s. 281.

36 Zob. W.A. Halland, Chinese medical jurisprudence [w:] Transactions of the China Branch of the Royal Asiatic Society, vol. 4, Hong Kong 1853-1854, s. 88-89.

37 A.F.P. Hulsewé, Remnants of Ch'in Law: An Annotated Translation of the Ch'in Legal and Administrative Rules of the $3^{\text {rd }}$ Century B.C. Discovered in Yün-Meng Prefecture, Hu-Pei Province, in 1975, Leiden 1985, s. 183-207.

38 Zob. Li Xueqin, Fantastic Stories in Fangmatan Bamboo Slips, „Cultural Relics” 1990, Issue 4, s. $43-47$.

39 C. Xinshan, H. Ruiting, The history of Chinese Forensic Medicine..., s. 79.

40 Zob. M. Roach, Satywniak - osobliwe ṡycie nieboszczylkón, Kraków 2019, s. 211. 
lekarzy ${ }^{41}$. Ogromny problem sprawiało im m.in. nastawianie zwichnięć. Na otwarte złamanie przykładano najczęściej kawałek świeżo zabitego kurczaka lub robiono okłady z jego krwi ${ }^{42}$. Po zakończeniu inspekcji Ling Shi sporządzali raport pisemny nazywany „Yuanshu”43. Był to pierwszy kryminalistyczno-medyczny raport wraz $\mathrm{z}$ raportem $\mathrm{z}$ badania terenu. Jak wynika z takich raportów, w czynnościach sądowo-lekarskich bardzo często brała udział cała rodzina poszkodowanego, a także niewolnicy pracujaccy dla wymiaru sprawiedliwości - Lichens.

\section{Okres Tang i Han}

W okresie panowania dynastii Han (206 r. p.n.e. - 220 r. n.e.) oraz dynastii Tang (618-907 r.) nastąpił rozwój farmakologii i toksykologii sądowo-lekarskiej. W odległym okresie zarówno Chińczycy, jak i Japończycy używali na wojnie zatrutych strzał, które - nasączone toksycznymi substancjami - niszczyły i osłabiały narządy wewnętrzne przeciwników ${ }^{44}$. Zainteresowanie truciznami nabrało znaczenia szczególnie w okresie dynastii Han, kiedy ówcześni cesarze próbowali stworzyć eliksir nieśmiertelności ${ }^{45}$. Pierwszym cesarzem, który zmarł na skutek zatrucia alchemicznym napojem, był prawdopodobnie Qin Shi Huang, zaś ostatnim Yongzheng ${ }^{46}$. W okresie panowania dynastii Tang co najmniej pięciu cesarzy zostało obezwładnionych i zabitych przez alchemiczny eliksir lub alchemiczne tabletki, które rzekomo miały zapewnić wieczność oraz władzę. Przyczyną śmierci cesarzy lub urzędników było prawdopodobnie zatrucie metalami (ołowiem, rtęcia czy arsenem $)^{47}$. Działania chińskich alchemików przyczyniły się do pogłębiania badań nad śmiercią gwałtowną w wyniku otrucia. Dla przykładu cesarz Muzong po objęciu tronu nakazał zabić wszystkich alchemików, którzy otruli jego ojca, po czym sam zaczął zażywać napoje nieśmiertelności. Jego urzędnik przestrzegał go wówczas przed przyjmowaniem środków „do leczenia chorób, które nie powinny być przyjmowane jako pokarm"48, a także zalecał rozwagę. Na dworze cesarskim

${ }^{41}$ Zob. G. Liu, Foundations of Theory for Ancient Chinese Medicine: Shang Han Lun and Contemporary Medical Texts, London - Philadelphia 2015, s. 24-39.

42 B. Madea, History of Medicine in Chinese Culture, Singapore 2020, s. 616-617.

43 Zob. A.F.P. Hulsevé, Remnants of Ch'in Law..., s. 182-185.

44 D.J. Macgowan, Notes on Chinese toxicology, ,Journal of the Shanghai Literary and Scientific Society" 1875, vol. IX, s. 173-175.

45 A. Coudert, Alchemy, the Philosopher's Stone, Boulder 1980, s. 184.

46 Zob. P. Marsone, Daoism under the Jurchen Jin Dynasty [w:] Modern Chinese Religion, vol. 1: SongLiao-Jin-Yuan (960-1368 AD), eds. J. Lagerwey, P. Marsone, Leiden - Boston 2014, s. 1142.

47 P.Y. Ho, F.P. Lisowski, A Brief History of Chinese Medicine, Singapore - New Jersey - London 1997, s. 39.

48 J. Needham, P.Y. Ho, Elixir poisoning in medieval China [w:] J. Needham, Clerks and Craftsmen in China and the West, Cambridge 1970, s. 319. 
w wyniku intryg dochodziło do otruć poprzez dodawanie arszeniku do chleba ${ }^{49}$. Artykuł 6 przywołanego niżej Kodeksu Tang wspomina o lekarzach żywności, którzy byli odpowiedzialni za osiem posiłków króla, a także za sposób ich przygotowywania zgodnie ze standardową książką kucharską ${ }^{50}$.

W czasach dynastii Tang dzięki działalności Chińskiego Cesarskiego Systemu Nauczania utworzono wydziały akupunktury, farmakologii oraz specjalności medycznych, w których nauczano również zagadnień związanych z medycyną sądową. Czynności sądowo-lekarskie przeprowadzali jednak wciąż urzędnicy.

Najwcześniej zachowany chiński kodeks feudalny Kodeks Tang (Táng lìi) ${ }^{51}$, ogłoszony w 653 r. jest najstarszym i najpełniejszym starożytnym chińskim kodeksem. Zawierał kilka przepisów dotyczących kar dla nieuczciwych śledczych, którzy nie prowadzili prawidłowo badania rannych lub martwych. Kodeks Tang w art. 382 poruszał również problematykę symulacji chorób, śmierci, a także ran. W art. 395 uregulowano odpowiedzialność medyka za błędy lekarskie, a także kary za błędne sporządzenie raportu kryminalistyczno-medycznego. Zgodnie z tym przepisem kara za niewłaściwe leczenie wynosiła pół roku niewoli ${ }^{52}$. Za błędnie sporządzony raport kryminalistyczno-lekarski prawo Tang karało powieszeniem. Przepisy art. 476-478 wyraźnie wskazywały na możliwość stosowania tortur podczas przesłuchania, ale jednocześnie zabraniały uciekania się do nich więcej niż trzy razy przed sądem ${ }^{53}$.

\section{Wu Zuo - inspektor (badacz) zwłok}

Wu Zuo (仵作), czyli inspektorzy sekcji zwłok pojawili się w okresie dynastii Yuan ${ }^{54}$. $W и$ Zuo dokonywali pośmiertnych badań i autopsji. Badanie ran było ich główną specjalnością. W literaturze anglojęzycznej termin ten został przetłumaczony jako

\footnotetext{
49 D.J. Macgowan, Notes on Chinese..., s. 173-179.

50 The T'ang Code, vol. I: Genera l Principles, trans. and introduction W. Johnson, Princeton 1979, s. 72.

51 Kodeks Tang jest najwcześniejszym chińskim kodeksem prawnym, jaki posiadamy w pełnej formie. Kodeks Tang był kodeksem karnym, który służył za model dla wszystkich późniejszych dynastycznych kodeksów prawa, w tym Song, Ming, Qing. Podzielony jest na dwie części - zasady ogólne i określone przestępstwa. W części szczegółowej każde przestępstwo jest nazwane i przewidziana jest za nie odpowiednia kara; zob. J. Chen, Chinese Law: Context and Transformation, Leiden - Boston 2015, s. 7-30.

52 The T'ang Code, vol. II: Specific articles, trans. and introduction W. Johnson, Princeton 1997, s. $545-549$.

53 Ibidem.

54 Przemianowani na „funkcjonariuszy śledczych” na początku XX w., Wu Zuo nadal pomagali urzędnikom sądowym i policji w ich dochodzeniach w przypadkach zgonów, często wykorzystując technologie badań kryminalistycznych opracowane podczas panowania dynastii Qing.
} 
„koroner”55. Pełnili funkcję asystentów urzędników państwowych, a także zajmowali się pogrzebami ${ }^{56}$. W końcu stali się formalnymi pracownikami urzędu rządowego w feudalnych Chinach aż do dynastii Qing (1644-1912). Wu Zuo uczestniczyli w chłostach i torturach. Następnie dokonywali oględzin ciała - ran, krwi i płynów ustrojowych. Jedną z cech stanowiska $W u$ Zuo było to, że osoby wykonujące tę pracę były oficjalnie zaklasyfikowane jako mające status „podłych ludzi” (jianmin), co stanowiło o ich sytuacji prawnej. Uniemożliwiało im to udział w egzaminach do służby cywilnej lub karierę urzędniczą ${ }^{57}$. Wu Zuo definiował status prawno-społeczny, który łączył funkcjonariuszy samorządowych, wykonujących zadania postrzegane jako służebne lub poniżające ${ }^{58}$.

Kluczową metodą ustalenia przyczyny zgonu było wykorzystanie wiedzy o tzw. punktach życiowych, czyli o częściach ciała, w przypadku których uraz może być śmiertelny ${ }^{59}$. Wu Zuo sprawdzali zwłoki publicznie od góry (głowy) do dołu (stóp) pod nadzorem urzędnika państwowego na miejscu zdarzenia. W przypadku kontuzji i zranień zapisywali miejsce ich położenia na ciele, rozmiar, długość, głębokość w „Trybie Badań Pośmiertnych” (驗屍方式), będących najstarszym oficjalnym dokumentem podobnym do współczesnych raportów medyczno-sądowych ${ }^{60}$. Poszukiwania kandydatów na $W u$ Zuo były żmudne, gdyż musieli spełniać surowe kryteria, m.in. mieć odpowiednie kwalifikacje (anlian) wynikające $z$ doświadczenia, jednak ich pozycja w tradycyjnym systemie biurokratycznym była niska. Z czasem zaczęły pojawiać się również nü Wu Zuo, czyli położne, których zadaniem było badanie części intymnych kobiet, jednak pierwsze wzmianki o „koronerkach” pojawiły się dopiero w XVIII stuleciu ${ }^{61}$. Wu Zuo byli wyznaczani w każdym hrabstwie oraz prowincji.

\section{„Oczyszczanie ze złych uczynków”}

Pierwszy tekst, który ściśle poruszał zagadnienia medycyny sądowej, pojawił się w wiekach średnich, w XIII stuleciu pod koniec dynastii Song. W 1247 r. Song Ci

55 D. Asen, Dead Bodies and Forensic Science: Cultures of Expertise in China, 1800-1949, New York 2012, s. 40.

56 A. Hansson, Chinese Outcasts: Discrimination and Emancipation in Late Imperial China, Leiden New York - Köln 1996, s. 49-50.

57 D. Asen, Death in Beijing: Murder and Forensic Science in Republican China, Cambridge 2016, s. 65.

58 Ibidem.

59 B. McKnight, The Washing away of Wrongs. Song Tz'u: Forensic Medicine in Thirteenth-Century China, Ann Arbor 1981, s. 7.

${ }^{60}$ C. Xinshan, H. Ruiting, The history of Chinese Forensic Medicine..., s. 83.

61 Dowiadujemy się o tym z wydanego w 1739 r. memoriału pałacowego napisanego przez Liu Fanga (劉放), wiceprezesa Ministerstwa Personelu, który zaproponował utworzenie stanowiska kobiet koronerów we wszystkich sądach powiatowych i sądach subprefektur. 
(lub Sung Tz’u) ${ }^{62}$, lekarz i urzędnik sądowy skompletował Xi yuan jilu (洗冤集錄), czyli „zapiski dotyczące zmywania zła”. W ten sposób powstał pierwszy obszerny podręcznik Hsi yüan chi lu dotyczący przeprowadzania sekcji zwłok, który stał się podstawą chińskiej praktyki kryminalistycznej. Song Ci uznawany jest do dziś za ojca medycyny sądowej na całym świecie ${ }^{63}$. Autor połączył własne doświadczenia medyka sądowego, sędziego i antropologa z różnymi przypadkami kryminalistycznymi ${ }^{64}$. Jego dzieło było przeznaczone zarówno dla prawników, jak i lekarzy, a myślą przewodnią było zapobieżenie pomyłkom sądowym. Hsi yüan chi lu zostało przedrukowane po raz pierwszy w $1400 \mathrm{r}$. i składało się z 5 ksiag: 1) Ogólne badanie sadowo-lekarskie, 2) Obrażenia ciała i ich symulacja, poronienia, 3) Sposoby powstawania obrażeń, narzędzia i przeszycie obražen, 4) Uduszenie i utopienie, 5) Trucizny i otrucia ${ }^{65}$.

${ }^{62}$ Song Ci 宋慈 (1186-1251) był chińskim naukowcem, pisarzem, lekarzem, medykiem sądowym, a także sędzią i antropologiem. Wykonywał swoje obowiązki w sądzie karnym w prowincji Hunan. Osobiście badał przypadki zabójstw, łącząc własne doświadczenia z historycznymi przypadkami kryminalistycznymi, dzięki czemu powstał esej Xi Yuan Ju Li. Autor przedstawił w nim swoje doświadczenia i wnioski mające pomóc przyszłym badaczom uniknąć błędów podczas śledztwa.

63 E.T. Withington, Medical History from the Earliest Times: A Popular History of the Healing Art, London 1894, s. 363.

${ }^{64} \mathrm{H}$. Jahong, Back from the Dead: Wrongful Convictions and Criminal Justice in China, Honolulu 2016, s. 11.

${ }^{65} \mathrm{~W}$ pierwszym tomie wymieniono przepisy dotyczące sędziów medycyny sądowej, zastosowane procedury biurokratyczne, liczbę dochodzeń, które należy przeprowadzić w odniesieniu do przestępstwa oraz osoby odpowiedzialne za ich przeprowadzenie, jurysdykcje, protokół postępowania inspektorów, sporządzanie raportów kryminalistycznych oraz kary, jakie mogą otrzymać eksperci medycyny sądowej, jeśli dokonają błędnych ocen. W tomie drugim wyszczególniono etapy rozkładu zwłok, ich zróżnicowanie w zależności od pory roku, mycie i przygotowywanie zwłok, badanie zwłok wyciąniętych z pochówku, ekshumację zwłok, metody badania zwłok w zaawansowanym stadium rozkładu, entomologię kryminalistyczną, analizy, jakie należy wykonać w przypadku uduszenia, różnice w spojrzeniu na zwłoki kobiet oraz badanie płodów. W trzecim tomie szczegółowo opisano kości, ślady ran na szkieletach, punkty życiowe ciała, samobójstwa przez powieszenie, symulowane samobójstwa, morderstwa i utonięcia. Czwarty tom opisywał zgony spowodowane uderzeniami lub kopnięciami lub tępymi narzędziami używanymi do dźgania lub cięcia, samobójstwa popełnione przy użyciu ostrych przedmiotów, morderstwa z powodu kilku ran, w których należało zidentyfikować śmiertelny cios, przypadki ścięcia głowy lub przypadki, w których tors było oddzielony od reszty ciała, zgony spowodowane oparzeniami, zgony spowodowane rozlaniem wrzacych płynów, zatrucia, zgony spowodowane chorobami ukrytymi, zgony spowodowane akupunktura. Piąty dotyczył śledztw w sprawie śmierci więźniów; opisano w nim zgony spowodowane torturami, zgony spowodowane upadkiem z dużych wysokości, zgony spowodowane zmiażdżeniem, uduszeniem, tupotami koni lub bawołów oraz wypadkami, śmierć przez uderzenie pioruna, zgony spowodowane atakami dzikich zwierząt, zgony spowodowane ukąszeniami owadów, węża lub gadów, zgony z powodu ran wewnętrznych, przejadania się, z powodu ekscesów seksualnych, wreszcie procedury otwierania zwłok, a także metody rozpraszania smrodu i przeprowadzania resuscytacji. 
Jak wynika z zapisków Song Ci, w Chinach już wiele stuleci wcześniej prowadzono ekspertyzy kryminalistyczne w przypadkach śmierci gwałtownej oraz zgonów budzących wątpliwości. Biurokraci byli odpowiedzialni za prowadzenie śledztw w ramach swych obowiązków ${ }^{66}$. Eksperci medyczni, będący odpowiednikami koronerów lub położnych, byli proszeni o badanie zwłok podczas śledztwa ${ }^{67}$. Jak wynika z tłumaczenia Briana McKnighta z 1981 r., eksperci medyczni nie budzili zaufania, ponieważ nie byli urzędnikami państwowymi ${ }^{68}$. Zadaniem biurokratów (bureaucrats) była więc obecność podczas sekcji zwłok, a następnie potwierdzenie ustaleń ekspertów medycznych ${ }^{69}$. Dokonując takiego potwierdzenia, musieli wskazać konkretną ranę odpowiedzialną za śmierć, rozróżnić zgony przypadkowe od zamierzonych, a także rany przedśmiertne (peri-mortem) od ran pośmiertnych (post-mortem) ${ }^{70}$.

W tłumaczeniu B. McKnighta Song Ci przedstawił, w jaki sposób średniowieczni naukowcy badali ciała kobiet oraz mężczyzn, jakie techniki antropologiczne i kryminalistyczne były stosowane. Przykładowo, badając kości, Song Ci zakładał, że każdy człowiek ma ich 365, gdyż były one odpowiednikiem 365 dni roku. Zdaniem autora kości mężczyzn są białawe, a u kobiet są ciemniejsze, ponieważ kiedy kobiety rodza, ich kości wytwarzają krew jak strumień wody. Jeśli ktoś połknie truciznę, kości również będą ciemne. Należy to bardzo dokładnie zbadać przed podjęciem decyzji, czy kości powinny być uznane za jasne lub ciemne. Dalej tłumaczył on budowę czaszek: „u mężczyzn jest łącznie osiem płytek, licząc od karku do uszu, łącznie z płytkami z tyłu czaszki. Z tyłu czaszki znajduje się poziomy szew, a pionowy biegnie do linii włosów na plecach. U kobiet jest tylko sześć talerzy. Z tyłu czaszki jest poziomy szew, ale nie ma szwu pionowego" ${ }^{17}$.

Dzieło Song Ci wyprzedziło o ponad 300 lat pracę włoskiego lekarza sądowego Fortunato Fideliego z 1602 r. pt. De realtionibus medicorum, która zawierała wszystkie poruszone zagadnienia ${ }^{72}$. Hsi yüan chi lu jest pierwszą na świecie systematyczna praca w zakresie medycyny sądowej, w szczególności w zakresie sekcji zwłok i ustalenia przyczyny zgonów. W książce znajdujemy również wiele szczegółów osteologicznych i anatomicznych, jak opis wykonania testu pokrewieństwa poprzez upuszczanie krwi z żywej osoby na kości zmarkego ${ }^{73}$. Jeżeli krew wsiąkała w kość, wówczas między osobami występowało pokrewieństwo. Sekcje zwłok ówcześnie były rzadko stosowane,

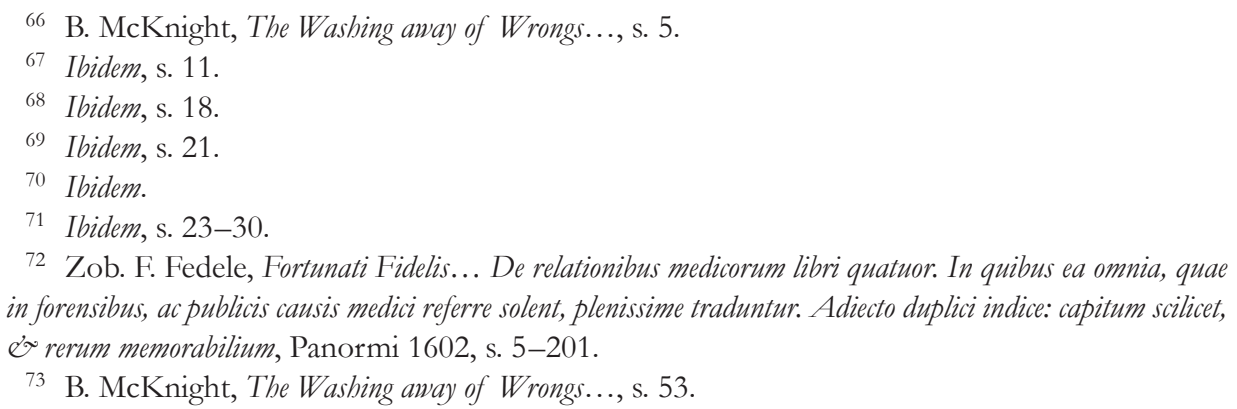


dlatego też Song Ci opisał szczegółowo oznaki uduszenia, powieszenia, utopienia, spalenia, samobójstwa na podstawie zewnętrznych oznak śmierci. W jednym z przypadków autor stwierdził, że nie doszło do samobójstwa. Nóż, którym wieśniak rzekomo popełnił samobójstwo, był zbyt luźno ułożony w dłoni, zaś na ciele znaleziono ranę kłutą. W wyniku dodatkowego śledztwa okazało się, że faktycznie właściciel ziemski zabił chłopa, a następnie włożył nóż w rękę ofiary ${ }^{74}$.

\section{Podsumowanie}

Opiniowanie sądowo-lekarskie było znane i praktykowane w Chinach od najdawniejszych dziejów. W okresie starożytnym znano już takie pojęcia, jak uraz skóry (shang), uraz ciała z krwią (chuang) czy uraz kości i mięśni (zhe). Świadczą o tym choćby bambusowe paski pochodzace z III w. p.n.e. Przez kilka tysięcy lat oględziny, obdukcje i inne czynności sądowo-lekarskie były zarezerwowane dla urzędników. Poza wiedzą prawna mieli oni również namiastkę wiedzy medycznej. Ówcześni lekarze byli przede wszystkim zobligowani do służenia na dworze i leczenia rodzin królewskich, dlatego też przy czynnościach sądowo-lekarskich pojawiali się sporadycznie lub wcale. Negatywny wpływ na rozwój medycyny sądowej miała również religia (m.in. konfucjanizm ${ }^{75}$ ) oraz doszukiwanie się połączenia między ludzkim ciałem a kosmosem (tzw. medycyna magiczna). Anatomiczne sekcje zwłok były przez długi czas zakazane, zaś poziom wiedzy medycznej był niski (wpływały na to m.in. brak wykonywania odpowiednich badań embriologicznych, skupianie się na ziołolecznictwie i medycynie naturalnej).

Pierwszą monografią dotyczącą medycyny sądowej na świecie jest Xiynan Jilu autorstwa Song Ci z południowej dynastii Song. Została napisana w 1247 r. i jest najwcześniejszą na świecie książką dotyczącą medycyny sądowej, w której autor poruszył problematykę udziału lekarzy przy dochodzeniach sądowo-lekarskich. Warto dodać, że w Europie pierwszym takim dziełem była praca Fortunato Fiedliego, a także Questiones medico-legales z 1621 r. pióra włoskiego medyka Paolo Zacciii ${ }^{76}$. W 1690 r. niemiecki lekarz Johannes Bohn jako pierwszy medyk w Europie użył określenia medicina forensis - medycyna sądowa, porównując ją do efektu, jaki wywołała medycyna będąca „wiernym asystentem” prawa ${ }^{77}$. Jest to dowód na to, że

\footnotetext{
74 Ibidem, s. 134.

75 Konfucjusz zakazywał m.in. dotykania nożem ciała (zarówno martwego, jak i żywego). Takie zabiegi jego zdaniem mogły naruszyć kult świętości ludzkiego ciała. Zbyt szybka śmierć wytwarzała zło, gdyż uaktywniała działania demonów. W efekcie tych konfucjańskich zaleceń chirurgia $i$ anatomia nie rozwijały się na odpowiednim poziomie.

76 P. Zacchia, Quaestiones medico-legales in tres tomos divisae, vol. 1-3, Lugduni 1726, s. 200-244.

77 J. Bohn, Specimen primum medicinae forensis, qvod superiorum prescitu \& assensu publico eruditorum examini submittit Johannes Bohn, ... respondente Joh. Gabriele Rudolff, Halo-Saxone. d. 5. Septembris 1690, Lipsiae 1690, s. 2-5.
} 
chińskie opiniowanie sądowo-lekarskie zostało zbadane kilka wieków wcześniej niż w Europie. Dzieło Song Ci (lub Sung Tzu) rozprzestrzeniło się za granicą i zostało przetłumaczone na języki angielski, francuski, holenderski, niemiecki, koreański, japoński i rosyjski. Jedną z innowacji rządu Qing było ogłoszenie rozszerzonej, poprawionej wersji tekstu, który służył jako oficjalny standard prowadzenia dochodzeń w sprawie śmierci. Przez setki lat opiniowanie sądowo-lekarskie było zagadnieniem pomijanym oraz tajemniczym, zaś nowoczesna medycyna sądowa powstała w Chinach dopiero w latach 30. XX stulecia ${ }^{78}$. Jej pionierem był profesor Lin Ji, który założył pierwszą Katedrę Medycyny Sądowej na Uniwersytecie w Pekinie.

\title{
SUMMARY
}

\author{
CHINESE FORENSIC MEDICINE - FROM ANTIQUITY \\ TO THE MIDDLE AGES. HISTORICAL AND LEGAL OUTLINE
}

The article shows the beginnings of forensic medical opinions in China in antiquity and the Middle Ages. The issues of the participation of experts - experts in matters related to the assessment of health and life were discussed. In addition, the length and tradition of Chinese forensic medicine that has developed since the dawn of time is highlighted. For hundreds of years, inspections and forensic examinations were carried out by government officials - not by doctors. Significant changes in this matter were introduced by Song $\mathrm{Ci}-$ a doctor and a judge who is considered to be the "father" of forensics around the world. His work, The Washing Away of Wrongs, changed the fate of forensic and medical opinion in the history of China.

78 C. Xinshan, H. Ruiting, The bistory of Chinese Forensic Medicine..., s. 85-89. 